\title{
Actual Problems of the Russian Economy
}

\author{
V.V. Moiseev ${ }^{1, *}$, S.I. Kramskoy ${ }^{1}$, E.A. Karelina ${ }^{2}$ and M.Yu. Karelina ${ }^{3}$ \\ *Corresponding author: din_prof@mail.ru \\ ${ }^{1}$ Shukhov Belgorod State Technological University, 46 Kostyukova St., Russia, Belgorod, 308012, \\ ${ }^{2}$ Moscow State University of Technology «STANKIN» 1 Vadkovsky lane, Moscow, 127055, Russia ${ }^{3}$ Moscow Automobile and Road \\ State Technical University Leningradsky prospect 64, 125319 Moscow Russia
}

\begin{abstract}
The urgency of researching the problems of the Russian economy is beyond doubt. It is determined by the scale and complexity of the tasks set by President V. Putin in 7the May 2018 decree. The purpose of the study is to study the current problems of the Russian economy and, on this basis, offer recommendations for their elimination in order to achieve the indicators indicated by the head of state and above all - enter the TOP-5 largest economies of the world.

The main objectives of the study were: 1 . To identify the main problems of the Russian economy. 2. To analyze the current shortcomings policy. 3 . To show the conditions under which the economy can develop at a pace. When studying the main issues of the topic, the authors use the following methods: dialectic, system-functional, economic-statistical, and formal-logical methods; the method of comparative analysis was used by the authors for comparison with the economies of other countries, for example, with the economy of China.

In this article, the authors attempted to analyze the main current problems of the Russian economy in order to show which "baggage" should be eliminated in the near future, which priority tasks should be solved in order to make a planned breakthrough in socio-economic development and get into the TOP-5 largest economies in the world.
\end{abstract}

Keywords: presidential decree, ambitious plans, problems in the economy.

\section{Introduction}

President V. Putin in order to implement the breakthrough scientific, technological and socio-economic development of the country, issued a decree "On the National Goals and Strategic Objectives of the Development of the Russian Federation for the Period up to 2024" in May 2018. According to the decree, Russia should enter the TOP-5 of the largest economies in the world by the end of the next term of Putin's government, and the country's GDP growth should exceed the global level [1].

In pursuance of the decree issued by the head of state, the government has developed 12 national projects, the implementation of which, in the opinion of Prime Minister D. Medvedev, makes it possible to accomplish the daunting tasks of breakthrough development, a sort of economic leap or economic miracle.

In the world economic literature, attention is paid to the questions of the theory of a big leap and conceptual approaches to the accelerated development of the economy [2-11]. Many economists studied problems modernization and economic growth, focusing on investment and innovation [7, 12-16]. However, the national peculiarities of the economic development of Russia at the present time were not noted. The authors are trying to reposition this gap in some way.

\section{Problem Statement}

A number of problems have accumulated in the Russian economy that requires an immediate solution. A substantial part (by some estimates, more than 40\%) of the production capacities in Russia is outdated not only physically, but most importantly - technologically; unfortunately, industrial production in Russia cannot yet produce innovative, competitive products that are in demand on the world market, namely: numerical control machines, modern cars, computers, televisions, iPhones, other high-tech products [10]. For the development of the processing industries and the replacement of outdated equipment, substantial material and, above all, financial resources are required, but at present the state does not have the necessary funds for economic modernization, as it is eloquently shown by the state budget adopted for 2019 and the following two years. Thus, in 2019, the state budget of Russia allocated only $12.5 \%$ of the expenditure side for modernization and development of the economy, which is significantly less than the planned expenditures on national defense - 14.7\% [4]. And this is despite the fact that the budget surplus for 2019 is planned in the amount of 1.8 trillion rubles, which will lie dead in one of the reserve funds and will be spent in case of sharp drops in the prices of oil, gas and other raw materials.

In energy efficiency and logistics, Russia lags far behind its competitors in the rest of the world. The Russian economy requires 4 times more energy than Japan. And the cost of transportation, storage and customs clearance in Russia is much higher than even in developing countries. Thus, the competitiveness of industrial goods is reduced, and this is an obstacle to the expansion of sales and production markets. 
In the area of production capacity, Russia is increasingly suffering from a shortage of labor resources, they are reduced by $0.5 \%$ per year for natural demographic reasons. At the same time, most of the workforce is employed in areas with zero or very low added value: public service, security forces, private security, trade and highly inefficient banking. The rest does not cover the needs of the country. Even with the current level of development of production and service in Russia, there is a catastrophic shortage of engineering and technical personnel, highly skilled workers and effective managers.

Another acute and very important problem of the Russian economy is the presence of raiding and the lack of security of entrepreneurs and their business. According to our calculations, over the past 9 years, more than 2 million businessmen have been subjected to lengthy arrests for alleged economic crimes in order to seize profitable enterprises and seize property.

As practice shows, article 159 of the Criminal Code of the Russian Federation is often used as a tool for in order to seize business or weaken competitors. The preliminary investigation bodies investigate criminal cases for years, extending the arrest of businessmen. As a result, firms and enterprises, without receiving proper guidance, fall into decay, go bankrupt. According to statistics, more than 100 thousand companies stop their business activities in Russia annually due to the criminal prosecution of managers.

President of Russia V.V. Putin is aware of this problem. In his message to the Federal Assembly of December 3, 2015 it was noted: "During 2014 the investigating authorities instituted almost 200 thousand criminal cases on the socalled economic compositions. 46 thousand out of 200 thousand reached the court, 15 thousand more cases fell apart in court... That is, they were set under pressure, robbed and released. And this, of course, is not what we need in terms of the business climate. This is a direct destruction of the business climate".

Another acute problem is closely related to the unsolved problem of the oppression of businessmen - capital flows from Russia. The authors calculated: from 2008 to 2018. 743 billion US dollars have been withdrawn from Russia. At the rate of the Central Bank of the Russian Federation on 02/01/2019, this amount exceeds 50 trillion rubles or almost three annual Russian Federation's budgets. This huge money did not turn into investment in the domestic economy, did not become a means for building new high-tech enterprises producing innovative products but were invested in the economy of potential competitors. Today, offshore companies are becoming a real obstacle to the formation of a proper business climate in the country, reducing the level of confidence in its economy from foreign partners and investors [8]. Therefore, President V. Putin has repeatedly stated that the state needs to support domestic business, create conditions that make it profitable for it to invest in the domestic economy and industry. For this purpose, it is necessary to create comfortable conditions for doing business in Russia, reduce corruption in government bodies, and so on.

\section{Research Questions}

In this study, the authors consider the following questions. 1. To identify the main problems that hinder the development of the Russian economy. 2. To analyze the main shortcomings in the implementation of state economic policy in modern conditions. 3 . To show the conditions under which the Russian economy can develop at a faster pace than at present.

\section{Purpose of the Study}

The purpose of the study is to study the current problems of the Russian economy, to show what hinders its growth. On the basis of the conducted research, we propose recommendations for accelerating economic development.

\section{Research Methods}

When studying the main issues of the topic, the authors use the following methods: 1) the institutional method that allows analyzing the role of the President, the government and other authorities in the implementation of economic policy; 2) the systemic, as well as structural and functional approaches, allowing to form a holistic and objective view of the state of the Russian economy, to note both positive aspects and the existing shortcomings in its development in modern conditions; 3 ) the method of comparative analysis was used by the authors for comparison with the economies of other countries, for example, with the economy of China; 4) the study also used the methods of analysis and synthesis, statistical and other methods for determining the current trends in the economic development of Russia.

\section{Findings}

As conclusions, the following should be noted.

First, in order to fulfill the ambitious task of joining the TOP-5 of the world's largest economies, the economic strategy should be revised, economic structural reforms that were long overdue should be carried out, and the authorities and businesses should strengthen their interaction, refusing pressure on entrepreneurs from law enforcement agencies. 
Secondly, the experience of many developed countries shows that their economic power and competitiveness, their role and influence in the world economy, the level and quality of life of citizens largely depend on the success in the development of a "smart" knowledge-based economy. This was convincingly proved by Japan, South Korea, Singapore and other states $[9,17]$ whose economy was based on innovation, high technology, including the digital economy. If the leading countries are actively moving in the direction of the sixth technological order, then the Russian industry is in the third, fourth, and only partially in the fifth technological order. And in order not to fall behind for a long time, it is necessary to train engineering and technical personnel meeting the needs of the innovative development of the economy.

Thirdly, for the implementation of the May 2018 presidential decree, factors constraining the innovative development of modern Russia, including corruption, insufficient government efficiency, and increasing labor productivity in industry, agriculture, construction and other sectors of the economy should be eliminated.

Fourthly, to correct the existing situation, it is necessary to unite the efforts of the state, science and business, to organize their interaction in achieving the goals formulated by President V. Putin in his message to the Federal Assembly on March 1, 2018. According to the authors, the following factors will contribute to the sustainable economic development of the Russian economy: optimization of Russia's participation in the global economy with an orientation on economic independence policy; priority of stimulating economic development over financial stabilization; correction of imbalances in the structure of the economy in favor of the real sector; implementation of large-scale state-building projects with the participation of private capital; introduction of modern management methods; focus on the digital economy and optimal development of labor resources.

\section{Conclusion}

The study showed that Russia has not yet created favorable conditions for doing business and developing the economy, as it has been done in more advanced countries. In 2017, in the world ranking of Doing Business, Russia ranked 35, and this position is not an honorable one. The difficulties of doing business in Russia are exacerbated by the tightening of Western sanctions. It is advisable for the political leadership of Russia to improve the business environment and to turn to the experience of Japan, China, Singapore and other developed countries of the world in order to use it creatively in their own country. Both China's experience and the Japanese and Singaporean "economic miracle" convincingly showed that by creating a favorable investment climate, by caring for comfortable conditions for entrepreneurs and by giving them all possible support, the state achieves impressive results in the economy.

Among key activities there are the development of affordable innovation infrastructure, the creation of industrial parks and the development of the institutional environment.

The authors of the article express the hope that President Vladimir Putin will use his new six-year term as head of state to change the attitude of the government towards the business for the better, reduce corruption and corporate raid, reduce capital outflows to offshore companies in order to bring Russia into a number of prosperous countries of the world.

\section{References}

1. Decree "On the national goals and strategic objectives of the development of the Russian Federation for the period up to 2024”. Retrieved from URL: http://kremlin.ru/events/president/news/57425. Accessed: 28.01.2019 (2018). [in Rus.].

2. P. Ackers, A Wilkinson, The British industrial relations paradigm: A critical outline history and prognosis. Journal of Industrial Relations, 47(4), 434-456. URL: https://research-repository.griffith.edu.au/handle/10072/15401. DOI: 10.1111/j.1472-9296.2005.00184.x (2005).

3. M. Alekseev, Comparative analysis of the development of Russia, the USA, Europe and China. ECO: All-Russian Economic Journal, 6, 113-122 (2012). [in Rus.].

4. Federal Law "On the Federal Budget for 2018 and for the Planning Period of 2019 and 2020” from 29.11.2018 N 458-FZ. Retrieved from URL: http://kremlin.ru/acts/bank/43845. Accessed: 28.01.2019 (2018). [in Rus.].

5. Ya. Juan, Capitalism in Chinese. State and business. Moscow: Alpina Publisher (2012). [in Rus.].

6. E.A. Karelina, Features of the socio-economic development of the PRC in the twentieth century, Bulletin of the Institute of Economics RAS, 2, 162-166. URL: https://cyberleninka.ru/article/n/osobennosti-sotsialnoekonomicheskogo-razvitiya-knr-v-hh-veke (2015). [in Rus.].

7. L.P. Kharchenko, New look at the financial markets of China. Moscow: Infra-M. (2016). [in Rus.].

8. V. Moiseev, E. Shurtukhina, Offshore economy. Man and Work, 8, 35-36. (2012). [in Rus.].

9. V.V. Moiseev, Russia in a global crisis. Moscow: Direct Media (2014). [in Rus.].

10. V.V. Moiseev, State policy of economic development of modern Russia (2000-2016). Moscow: Direct Media (2017).

11. M. Alexeev, Sh. Weber (Eds.), The Oxford handbook of the Russian economy, Oxford: Oxford University Press. DOI: 10.1093/oxfordhb/9780199759927.001.0001 (2013).

12. V.I. Balakin, China's investment strategy in the intercross period (1998-2008), Problems of the Far East, 4, 71-80. URL: https://elibrary.ru/item.asp?id=20210362 (2013). [in Rus.]. 
13. V. Kondratiev, Developed in China. Direct Investments, 1(2), 66-71. URL: https://elibrary.ru/item.asp?id=21214427 (2014). [in Rus.].

14. A.Yu. Plotnikov, China's investment policy in the context of the post-war economic development of the country Finance. Money. Investments, 4(52), 29-32. URL: https://elibrary.ru/item.asp?id=22592957 (2014). [in Rus.].

15.D.A. Smakhtin, Money and credit sector of the PRC at the present stage. Bank Services, 10, 14-19. URL: https://elibrary.ru/item.asp?id=20460639 (2013). [in Rus.].

16. L.V. Stakhovich, E.V. Semenkova, Experience of currency control over direct and portfolio investments in China. Finance, 12, 67-71. URL: https://elibrary.ru/item.asp?id=22847128 (2014). [in Rus.].

17. K.B. Bahtaraeva, Singapore: The role of the financial system in the "economic miracle." Finance and Credit, 39(663), 2-13 URL: https://cyberleninka.ru/article/n/singapur-rol-finansovoy-sistemy-v-ekonomicheskom-chude (2015). [in Rus.]. 